\title{
Descriptive review of junior OB/GYN physicians' work task financial compensation in German hospitals
}

\author{
Dörthe Brüggmann ${ }^{1,2}$, Anja Herpe ${ }^{2}$, David Quarcoo², Norman Schöffel ${ }^{2}$, Eileen M. Wanke², Daniela Ohlendorf ${ }^{2}$, \\ Doris Klingelhöfer ${ }^{2^{*}}\left(\mathbb{D}\right.$, David A. Groneberg ${ }^{2+}$ and Stefanie Mache ${ }^{3+}$
}

\begin{abstract}
Beginning in the first decade of the 21st centruy, there was a growing disregard for the benefits of the German medical system concerning the junior obstetricians/gynecologists (OB/GYN) job situation. As in other fields of medicine, numerous colleagues left Germany to work in other countries such as the United Kingdom, Noway, Sweden, or Switzerland. According to studies, financial factors represent one of the reasons for the discontent. We here present a practical descriptive approach to assess/review the actual compensation of single work tasks of OB/ GYNs on the basis of previously published, existing data. Using the workflow data from the Medical work Assessment in German hospitals (MAGRO) platform of twenty junior OB/GYNs with an average workday of 9:24:35 h $(S D=01: 05: 07 \mathrm{~h}$ ), a large scale data analysis of 2,325,556 different time points was performed to calculate the financial valuation of single work tasks. In order to assess the evolution over the past years, different modern and historic (e.g. AiP) pay scales were used and analysed in relation to the actual work on a weekly, monthly and per annum basis. Our review shows that there has been a dramatic increase in the financial reward of the practical work tasks of junior OB/GYN physicians in German hospitals in comparison to the situation of the early 2000s years. In this respect, it can not be further argued that the German system has large disadvantages concerning the payment of junior doctors in comparison to other European countries.
\end{abstract}

Keywords: Task analysis, Job situation, Compensation, Gynecology - obstetrics

\section{Introduction}

The common occupational health problem attributed to healthcare work is infection [1-9]. But healthcare workers also have a large variety of other job-related risk factors [10-13]. Over the past 20 years, a number of studies reported a growing discontent in job satisfaction among young physicians in the German health care system [1416]. Similar reports in the field of obstetrics and gynecology were reported in other countries [17-19]. These studies predominantly focused on factors such as occupational stress, satisfaction, and burnout $[20,21]$. Parallel to these reports, a high rate of young doctors left their country of

\footnotetext{
* Correspondence: klingelhoefer@med.uni-frankfurt.de

${ }^{\dagger}$ David A. Groneberg and Stefanie Mache contributed equally to this work.

${ }^{2}$ Division of Social Medicine, The Institute of Occupational Medicine, Social

Medicine and Environmental Medicine, Goethe University Frankfurt,

Theodor-Stern-Kai 7, 60590 Frankfurt, Germany

Full list of author information is available at the end of the article
}

origin for foreign work places and a high number of German hospitals currently encounter problems concerning junior residents. This severe problem targets one of the key fundaments of the health service - the pyramidal system of junior residents developing into specialists who then continue to work either as hospital or outpatient consultants.

Due to the magnitude of the problem concerning the shortage of junior staff and the ongoing complain concerning working conditions, the Medical work Assessment in German hospitals (MAGRO) platform was established in 2009 [22] and has focused on a variety of clinical fields including gynecology and obstetrics [23], general surgery [24], pediatrics, psychiatry [25], emergency care [26], or internal medicine [27, 28], so far. One of these previous studies showed hat the working conditions for junior $\mathrm{OB} /$ GYNs are by far not as bad as previously hypothesized. In a second step, MAGRO now focuses on economic aspects

(c) The Author(s). 2019 Open Access This article is distributed under the terms of the Creative Commons Attribution 4.0 International License (http://creativecommons.org/licenses/by/4.0/), which permits unrestricted use, distribution, and 
Table 1 Average times for main activities performed by obstetrician-gynecologists [10] and [23]

\begin{tabular}{llll}
\hline Categories & Average time of activity (hh:mm:ss) & SD (hh:mm:ss) & Percentage \\
\hline Ward rounds & $00: 21: 48$ & $00: 15: 19$ & 3.86 \\
Admission & $00: 05: 05$ & $00: 06: 23$ & 0.90 \\
Conversation & $02: 41: 56$ & $00: 33: 35$ & 28.68 \\
Medical consultation & $00: 39: 03$ & $00: 20: 09$ & 6.92 \\
Administrative work & $02: 09: 40$ & $00: 30: 59$ & 22.97 \\
Working with the patient & $00: 10: 38$ & $00: 09: 56$ & 1.88 \\
Supervision, social support & $00: 00: 04$ & $00: 00: 09$ & 0.01 \\
Diagnostics & $00: 14: 55$ & $00: 12: 48$ & 2.64 \\
Breaks & $00: 06: 02$ & $00: 05: 13$ & 1.07 \\
Walking & $00: 42: 03$ & $00: 14: 00$ & 7.45 \\
Operation & $01: 19: 11$ & $00: 55: 15$ & 14.03 \\
Research & $00: 00: 35$ & $00: 01: 46$ & 0.10 \\
Teaching & $00: 09: 08$ & $00: 20: 31$ & 1.62 \\
Medical emergency & $00: 00: 01$ & $00: 00: 04$ & 0.00 \\
Work disruptions & $00: 06: 03$ & $00: 03: 14$ & 1.07 \\
Pregnancy care & $00: 17: 57$ & $00: 22: 19$ & 3.18 \\
Other & $00: 20: 27$ & $00: 11: 15$ & 3.62 \\
\hline
\end{tabular}

in order to demonstrate that the increase in job quality is also present in this area.

In this respect, the present descriptive review focused on historic and current payment scales and relates them to the average work schedule of junior resident $\mathrm{OB} /$ GYNs. Since there has been a change in the status of young physicians, large differences can be anticipated and therefore, the hypothesis of the present review is that there has been an improvement in the esteem of single OB/GYNs work tasks.

\section{Materials and methods \\ Setting}

This descriptive review belongs to the Medical work Assessment in German hospitals (MAGRO) studies [22]. It aims to assess the improvement of payment aspects within the field of $\mathrm{OB} / \mathrm{GYN}$ over the past years by reviewing/analysing existing MAGRO data. The descriptive analysis is based on the data of a previous MAGRO study that

Table 2 Pay scales used to calculate compensation for main work tasks

\begin{tabular}{ll}
\hline Pay scales & $\begin{array}{l}\text { Pre tax salary } \\
\text { per month }(€)\end{array}$ \\
\hline Arzt im Praktikum (AiP) & $1350.57 €$ \\
TVöD Bund & $3431.28 €$ \\
TV-Ärzte (Helios) & $3900.00 €$ \\
TV-Ärzte (VKA) & $3947.67 €$ \\
TV-Ärzte (TdL) & $4260.59 €$ \\
\hline
\end{tabular}

performed a work task analysis of 20 physicians in OB/ GYN wards of three Berlin hospitals in order to provide reference data for daily work [23]. In brief, a work flow analysis was conducted with a mobile personal computer [29] and a special OB/GYN task inventory with 221 different medical activities, grouped into 18 categories (e.g. "telephone call" and "talking to a colleague" was grouped into the "conversation" category) [23] (Table 1). The interobserver reliability exceeded $80 \%$ and in total, $564: 35: 56 \mathrm{~h}$ were analysed to provide reference data. In this respect, the average workday of the obstetrician-gynecologists was 9:24:35 h ( $\mathrm{SD}=1: 05: 05$ h) [23]. The longest workday observed was 12:52:02 h, the shortest was $8: 02: 37 \mathrm{~h}$. Table 1 summarizes the main work-related activity tasks which were then used for further payment salaries [23].

\section{Salary scales and calculations}

In order to analyse differences in the appreciation of physicians work between the situation ten years ago and nowadays, former and current German pay scales were related to the reference values depicted in Table 1 . Out of the variety of over ten different pay scales in Germany, five pay scales were chosen which consist of one rate which was paid eight years ago to physicians in their second residential year after having finished the medical exams (Arzt im Praktikum) [30] and four current rates for physicians in the second year after the final medical exams (Table 2). They consist of two governmental (TVöD paid to federally employed physicians 
Table 3 Average compensation per main activity of physician in the AIP payment scale (work experience approx. 2 years)

\begin{tabular}{|c|c|c|c|c|c|c|}
\hline Categories & $\begin{array}{l}\text { Average time } \\
\text { main activities } \\
\text { (hh:mm:ss) }\end{array}$ & $\begin{array}{l}\text { SD time main } \\
\text { activities } \\
\text { (hh:mm:ss) }\end{array}$ & $\begin{array}{l}\text { Average compensation/ } \\
\text { main activity/day } \\
(€)\end{array}$ & $\begin{array}{l}\text { Average compensation/ } \\
\text { main activity/month } \\
\text { (€) }\end{array}$ & $\begin{array}{l}\text { Average compensation/ } \\
\text { main activity/year } \\
(€)\end{array}$ & $\begin{array}{l}\text { Percentage } \\
\text { of total }\end{array}$ \\
\hline Administrative work & 02:09:40 & $00: 30: 59$ & 14.47 & 313.52 & 3762.28 & $22.97 \%$ \\
\hline Medical consultation & 00:39:03 & 00:20:09 & 4.36 & 94.42 & 1133.04 & $6.92 \%$ \\
\hline Admission & 00:05:05 & $00: 06: 23$ & 0.57 & 12.29 & 147.49 & $0.90 \%$ \\
\hline Conversation & $02: 41: 56$ & $00: 33: 35$ & 18.07 & 391.54 & 4698.50 & $28.68 \%$ \\
\hline Research & 00:00:35 & $00: 01: 46$ & 0.07 & 1.41 & 16.93 & $0.10 \%$ \\
\hline Diagnostics & $00: 14: 55$ & $00: 12: 48$ & 1.66 & 36.07 & 432.81 & $2.64 \%$ \\
\hline Teaching & 00:09:08 & $00: 20: 31$ & 1.02 & 22.08 & 265.00 & $1.62 \%$ \\
\hline Medical emergency & 00:00:01 & 00:00:04 & 0.00 & 0.04 & 0.48 & $0.00 \%$ \\
\hline Surgery & 01:19:11 & $00: 55: 15$ & 8.84 & 191.46 & 2297.51 & $14.03 \%$ \\
\hline Work disruptions & 00:06:03 & 00:03:14 & 0.68 & 14.63 & 175.54 & $1.07 \%$ \\
\hline Pregnancy care & $00: 17: 57$ & $00: 22: 19$ & 2.00 & 43.40 & 520.82 & $3.18 \%$ \\
\hline Other & 06:49:01 & $00: 11: 15$ & 2.28 & 49.45 & 593.36 & $3.62 \%$ \\
\hline Supervision. social support & 00:00:04 & 00:00:09 & 0.01 & 0.16 & 1.93 & $0.01 \%$ \\
\hline Working with the patient & $00: 10: 38$ & 00:09:56 & 1.19 & 25.71 & 308.53 & $1.88 \%$ \\
\hline Ward round & $00: 21: 48$ & $00: 15: 19$ & 2.43 & 52.71 & 632.53 & $3.86 \%$ \\
\hline Walking time & $00: 42: 03$ & $00: 14: 00$ & 4.69 & 101.67 & 1220.08 & $7.45 \%$ \\
\hline
\end{tabular}

and TV-Ärzte (TdL) paid by physicians employed by single German states [31], a rate paid by a private hospital company (Helios) [32] and a rate paid by municipal hospitals (TV-Ärzte (VKA)) [33]). The single salary scale values were then used to calculate the average costs for single tasks per day, per month and per year.

\section{Results}

The calculation of salary percentages for single work tasks of junior hospital OB/GYN doctors in a setting of a total 564:35:56 h work hours led to a wide range of values with regard to the single tarifs and single work tasks which are depicted in Tables $3,4,5,6$, and 7 . In

Table 4 Average compensation per main activity of physician in the TVöD Bund payment scale (work experience approx. 2 years)

\begin{tabular}{|c|c|c|c|c|c|c|}
\hline Categories & $\begin{array}{l}\text { Average time } \\
\text { main activities } \\
\text { (hh:mm:ss) }\end{array}$ & $\begin{array}{l}\text { SD time main } \\
\text { activities } \\
\text { (hh:mm:ss) }\end{array}$ & $\begin{array}{l}\text { Average compensation/ } \\
\text { main activity/day } \\
(€)\end{array}$ & $\begin{array}{l}\text { Average compensation/ } \\
\text { main activity/month } \\
(€)\end{array}$ & $\begin{array}{l}\text { Average compensation/ } \\
\text { main activity/year } \\
(€)\end{array}$ & $\begin{array}{l}\text { Percentage } \\
\text { of total }\end{array}$ \\
\hline Administrative work & 02:09:40 & $00: 30: 59$ & 36.76 & 796.54 & 9558.51 & $22.97 \%$ \\
\hline Medical consultation & 00:39:03 & 00:20:09 & 11.07 & 239.88 & 2878.61 & $6.92 \%$ \\
\hline Admission & 00:05:05 & $00: 06: 23$ & 1.44 & 31.23 & 374.72 & $0.90 \%$ \\
\hline Conversation & $02: 41: 56$ & $00: 33: 35$ & 45.91 & 994.76 & $11,937.08$ & $28.68 \%$ \\
\hline Research & 00:00:35 & 00:01:46 & 0.17 & 3.58 & 43.00 & $0.10 \%$ \\
\hline Diagnostics & $00: 14: 55$ & $00: 12: 48$ & 4.23 & 91.63 & 1099.60 & $2.64 \%$ \\
\hline Teaching & 00:09:08 & $00: 20: 31$ & 2.59 & 56.11 & 673.27 & $1.62 \%$ \\
\hline Medical emergency & 00:00:01 & 00:00:04 & 0.00 & 0.10 & 1.23 & $0.00 \%$ \\
\hline Surgery & 01:19:11 & $00: 55: 15$ & 22.45 & 486.42 & 5837.08 & $14.03 \%$ \\
\hline Work disruptions & 00:06:03 & 00:03:14 & 1.72 & 37.17 & 445.98 & $1.07 \%$ \\
\hline Pregnancy care & $00: 17: 57$ & $00: 22: 19$ & 5.09 & 110.27 & 1323.20 & $3.18 \%$ \\
\hline Other & 06:49:01 & $00: 11: 15$ & 5.80 & 125.62 & 1507.49 & $3.62 \%$ \\
\hline Supervision. social support & 00:00:04 & 00:00:09 & 0.02 & 0.41 & 4.91 & $0.01 \%$ \\
\hline Working with the patient & $00: 10: 38$ & 00:09:56 & 3.01 & 65.32 & 783.85 & $1.88 \%$ \\
\hline Ward round & $00: 21: 48$ & $00: 15: 19$ & 6.18 & 133.92 & 1607.01 & $3.86 \%$ \\
\hline Walking time & $00: 42: 03$ & $00: 14: 00$ & 11.92 & 258.31 & 3099.76 & $7.45 \%$ \\
\hline
\end{tabular}


Table 5 Average compensation per main activity of physician in the TV-Ärzte (Helios) payment scale (work experience approx. 2 years)

\begin{tabular}{|c|c|c|c|c|c|c|}
\hline Categories & $\begin{array}{l}\text { Average time } \\
\text { main activities } \\
\text { (hh:mm:ss) }\end{array}$ & $\begin{array}{l}\text { SD time main } \\
\text { activities } \\
\text { (hh:mm:ss) }\end{array}$ & $\begin{array}{l}\text { Average compensation/ } \\
\text { main activity/day } \\
(€)\end{array}$ & $\begin{array}{l}\text { Average compensation/ } \\
\text { main activity/month } \\
\text { (€) }\end{array}$ & $\begin{array}{l}\text { Average compensation/ } \\
\text { main activity/year } \\
(€)\end{array}$ & $\begin{array}{l}\text { Percentage } \\
\text { of total }\end{array}$ \\
\hline Administrative work & 02:09:40 & 00:30:59 & 41.79 & 905.35 & $10,864.23$ & $22.97 \%$ \\
\hline Medical consultation & 00:39:03 & 00:20:09 & 12.58 & 272.65 & 3271.84 & $6.92 \%$ \\
\hline Admission & 00:05:05 & 00:06:23 & 1.64 & 35.49 & 425.91 & $0.90 \%$ \\
\hline Conversation & $02: 41: 56$ & $00: 33: 35$ & 52.19 & 1130.64 & $13,567.72$ & $28.68 \%$ \\
\hline Research & 00:00:35 & 00:01:46 & 0.19 & 4.07 & 48.88 & $0.10 \%$ \\
\hline Diagnostics & $00: 14: 55$ & $00: 12: 48$ & 4.81 & 104.15 & 1249.80 & $2.64 \%$ \\
\hline Teaching & 00:09:08 & $00: 20: 31$ & 2.94 & 63.77 & 765.24 & $1.62 \%$ \\
\hline Medical emergency & 00:00:01 & 00:00:04 & 0.01 & 0.12 & 1.40 & $0.00 \%$ \\
\hline Surgery & 01:19:11 & $00: 55: 15$ & 25.52 & 552.87 & 6634.44 & $14.03 \%$ \\
\hline Work disruptions & 00:06:03 & 00:03:14 & 1.95 & 42.24 & 506.90 & $1.07 \%$ \\
\hline Pregnancy care & $00: 17: 57$ & $00: 22: 19$ & 5.78 & 125.33 & 1503.96 & $3.18 \%$ \\
\hline Other & 06:49:01 & $00: 11: 15$ & 6.59 & 142.78 & 1713.42 & $3.62 \%$ \\
\hline Supervision. social support & 00:00:04 & 00:00:09 & 0.02 & 0.47 & 5.59 & $0.01 \%$ \\
\hline Working with the patient & $00: 10: 38$ & 00:09:56 & 3.43 & 74.24 & 890.92 & $1.88 \%$ \\
\hline Ward round & $00: 21: 48$ & 00:15:19 & 7.03 & 152.21 & 1826.53 & $3.86 \%$ \\
\hline Walking time & $00: 42: 03$ & $00: 14: 00$ & 13.55 & 293.60 & 3523.19 & $7.45 \%$ \\
\hline
\end{tabular}

Table 6 Average compensation per main activity of physician in the TV-Ärzte (VKA) payment scale (work experience approx. 2 years)

\begin{tabular}{|c|c|c|c|c|c|c|}
\hline Categories & $\begin{array}{l}\text { Average time } \\
\text { main activities } \\
\text { (hh:mm:ss) }\end{array}$ & $\begin{array}{l}\text { SD time main } \\
\text { activities } \\
\text { (hh:mm:ss) }\end{array}$ & $\begin{array}{l}\text { Average compensation/ } \\
\text { main activity/day } \\
(€)\end{array}$ & $\begin{array}{l}\text { Average compensation/ } \\
\text { main activity/month } \\
(€)\end{array}$ & $\begin{array}{l}\text { Average compensation/ } \\
\text { main activity/year } \\
(€)\end{array}$ & $\begin{array}{l}\text { Percentage } \\
\text { of total }\end{array}$ \\
\hline Administrative work & 02:09:40 & $00: 30: 59$ & 42.30 & 916.42 & $10,997.02$ & $22.97 \%$ \\
\hline $\begin{array}{l}\text { Medical } \\
\text { consultation }\end{array}$ & 00:39:03 & 00:20:09 & 12.74 & 275.99 & 3311.83 & $6.92 \%$ \\
\hline Admission & 00:05:05 & 00:06:23 & 1.66 & 35.93 & 431.12 & $0.90 \%$ \\
\hline Conversation & $02: 41: 56$ & $00: 33: 35$ & 52.82 & 1144.46 & $13,733.55$ & $28.68 \%$ \\
\hline Research & 00:00:35 & 00:01:46 & 0.19 & 4.12 & 49.47 & $0.10 \%$ \\
\hline Diagnostics & $00: 14: 55$ & $00: 12: 48$ & 4.87 & 105.42 & 1265.08 & $2.64 \%$ \\
\hline Teaching & 00:09:08 & $00: 20: 31$ & 2.98 & 64.55 & 774.60 & $1.62 \%$ \\
\hline $\begin{array}{l}\text { Medical } \\
\text { emergency }\end{array}$ & 00:00:01 & 00:00:04 & 0.01 & 0.12 & 1.41 & $0.00 \%$ \\
\hline Surgery & 01:19:11 & $00: 55: 15$ & 25.83 & 559.63 & 6715.53 & $14.03 \%$ \\
\hline Work disruptions & 00:06:03 & 00:03:14 & 1.97 & 42.76 & 513.10 & $1.07 \%$ \\
\hline Pregnancy care & $00: 17: 57$ & $00: 22: 19$ & 5.86 & 126.86 & 1522.34 & $3.18 \%$ \\
\hline Other & 06:49:01 & $00: 11: 15$ & 6.67 & 144.53 & 1734.36 & $3.62 \%$ \\
\hline $\begin{array}{l}\text { Supervision. } \\
\text { social support }\end{array}$ & 00:00:04 & 00:00:09 & 0.02 & 0.47 & 5.65 & $0.01 \%$ \\
\hline $\begin{array}{l}\text { Working with } \\
\text { the patient }\end{array}$ & $00: 10: 38$ & 00:09:56 & 3.47 & 75.15 & 901.81 & $1.88 \%$ \\
\hline Ward round & $00: 21: 48$ & 00:15:19 & 7.11 & 154.07 & 1848.86 & $3.86 \%$ \\
\hline Walking time & $00: 42: 03$ & 00:14:00 & 13.72 & 297.19 & 3566.26 & $7.45 \%$ \\
\hline
\end{tabular}


Table 7 Average compensation per main activity of physician in the TV-Ärzte (TdL) payment scale (work experience approx. 2 years)

\begin{tabular}{|c|c|c|c|c|c|c|}
\hline Categories & $\begin{array}{l}\text { Average time } \\
\text { main activities }\end{array}$ & $\begin{array}{l}\text { SD time main } \\
\text { activities }\end{array}$ & $\begin{array}{l}\text { Average compensation/ } \\
\text { main activity/day }\end{array}$ & $\begin{array}{l}\text { Average compensation/ } \\
\text { main activity/month }\end{array}$ & $\begin{array}{l}\text { Average compensation/ } \\
\text { main activity/year }\end{array}$ & $\begin{array}{l}\text { Percentage } \\
\text { of total }\end{array}$ \\
\hline & (hh:mm:ss) & (hh:mm:ss) & $(€)$ & $(€)$ & $(€)$ & \\
\hline Administrative work & 02:09:40 & $00: 30: 59$ & 45.65 & 989.06 & $11,868.72$ & $22.97 \%$ \\
\hline Medical consultation & 00:39:03 & 00:20:09 & 13.75 & 297.86 & 3574.35 & $6.92 \%$ \\
\hline Admission & 00:05:05 & $00: 06: 23$ & 1.79 & 38.77 & 465.29 & $0.90 \%$ \\
\hline Conversation & $02: 41: 56$ & $00: 33: 35$ & 57.01 & 1235.18 & $14,822.17$ & $28.68 \%$ \\
\hline Research & 00:00:35 & 00:01:46 & 0.21 & 4.45 & 53.39 & $0.10 \%$ \\
\hline Diagnostics & $00: 14: 55$ & $00: 12: 48$ & 5.25 & 113.78 & 1365.36 & $2.64 \%$ \\
\hline Teaching & 00:09:08 & $00: 20: 31$ & 3.22 & 69.67 & 836.00 & $1.62 \%$ \\
\hline Medical emergency & 00:00:01 & 00:00:04 & 0.01 & 0.13 & 1.53 & $0.00 \%$ \\
\hline Surgery & 01:19:11 & $00: 55: 15$ & 27.88 & 603.99 & 7247.85 & $14.03 \%$ \\
\hline Work disruptions & 00:06:03 & 00:03:14 & 2.13 & 46.15 & 553.77 & $1.07 \%$ \\
\hline Pregnancy care & $00: 17: 57$ & $00: 22: 19$ & 6.32 & 136.92 & 1643.01 & $3.18 \%$ \\
\hline Other & 06:49:01 & $00: 11: 15$ & 7.20 & 155.99 & 1871.84 & $3.62 \%$ \\
\hline Supervision. social support & 00:00:04 & 00:00:09 & 0.02 & 0.51 & 6.10 & $0.01 \%$ \\
\hline Working with the patient & $00: 10: 38$ & 00:09:56 & 3.74 & 81.11 & 973.30 & $1.88 \%$ \\
\hline Ward round & $00: 21: 48$ & $00: 15: 19$ & 7.67 & 166.28 & 1995.41 & $3.86 \%$ \\
\hline Walking time & 00:42:03 & $00: 14: 00$ & 14.80 & 320.75 & 3848.94 & $7.45 \%$ \\
\hline
\end{tabular}

total, a magnitude of 2,325,556 different time points were related to the different work tasts and then the average financial compensation per work task was calculated for the different payment scales: The lowest values were found in the historic AiP payment scale. In this scale which was used until 2004, the average compensation i.e. for the work task "adminstrative work" (02:09:40 +/- 00:30:59 hh:mm:ss per day) was $14.47 €$ per day, $313.52 €$ per month and $3762.28 €$ per year (Table 3 ). By contrast, in the payment scale for physicians employed by the federal government the exactly same task is valued $36.76 €$ per day, $796.54 €$ per month and $9558.51 €$ per year (Table 4). In the Helios payment scale, the adminstrative work is compensated with $10,864.23 €$ per year (Table 5), in the payment scale for municipally employed physicians with $8833.45 €$ per annum (Table 6) and in the current payment scale of the German states (TdL) which is i.e. paid at the university schools of medicine in some of the 16 German states, this work category is valued $11,868.72 €$ (Table 7). That means that not longer than eight years prior to the last time point here observed, a physicians work force at this stage of the career was valued less than $1 / 3$ of todays valuation.

The leading work task concerning the time is the conversation with colleagues and staff members. This time period of 2:41:56 +/-0:33:35 h was compensated with $18.07 €$ per day in the AiP scale (391.54 $€$ per month and $4698.50 €$ per year, Tab. 3$), 45.91 €$ per day in the TVöD Bund payment scale (994.76 € per month and 11,937.08 € per year, Tab. 4), $52.19 €$ per day in the TV Helios
(1130.64 $€$ per month and $13,567.72 €$ per year, Tab. 5), $52.82 €$ per day in the TV-Ärzte (VKA) payment scale (1144.46 € per month and $13,733.55 €$ per year, Tab. 6), and $57,01 €$ per day in the TV-Ärzte (TdL) payment scale (1235.18 € per month and $14,822.17$ per year, Tab. 7).

When comparing the different payment scales, i.e. by focusing on the lowest payment scale and the highest (Fig. 1), large differences are found. I.e. when analysing the pure walking time of $42+/-14 \mathrm{~min}$ per day, it can be seen that this category is currently valued $320.75 €$ per month $(3848.94 €$ per year) in the TdL scale. This is even higher than the amount of money directed to adminstrative work (over 2 $+/-0.5 \mathrm{~h} / \mathrm{d}$ ) in the historic AiP scale (313.52 € per month/ $3762.28 €$ per year) which was paid for doctors of the same qualification (2 years of experience) until 2004 (Fig. 1).

\section{Discussion}

Among the numerous occupational problems found in health care personel [34-42], there are many studies that address career satisfaction and perceptions of quality among obstetricians and gynecologists [17, 19, 43-46]. The present article does not want to add a further questionnairy-based survey which asks physicians for their attitude concerning job situation, payment or other factors but addresses a difficult area - namely the field of young academics in the field of obstetrics and gynecology - by reviewing existing real-time analysis data and correlating this data to tarfis. After having previously recorded reference values for daily work activities of junior OB/GYN physicians [23], the aim of this 


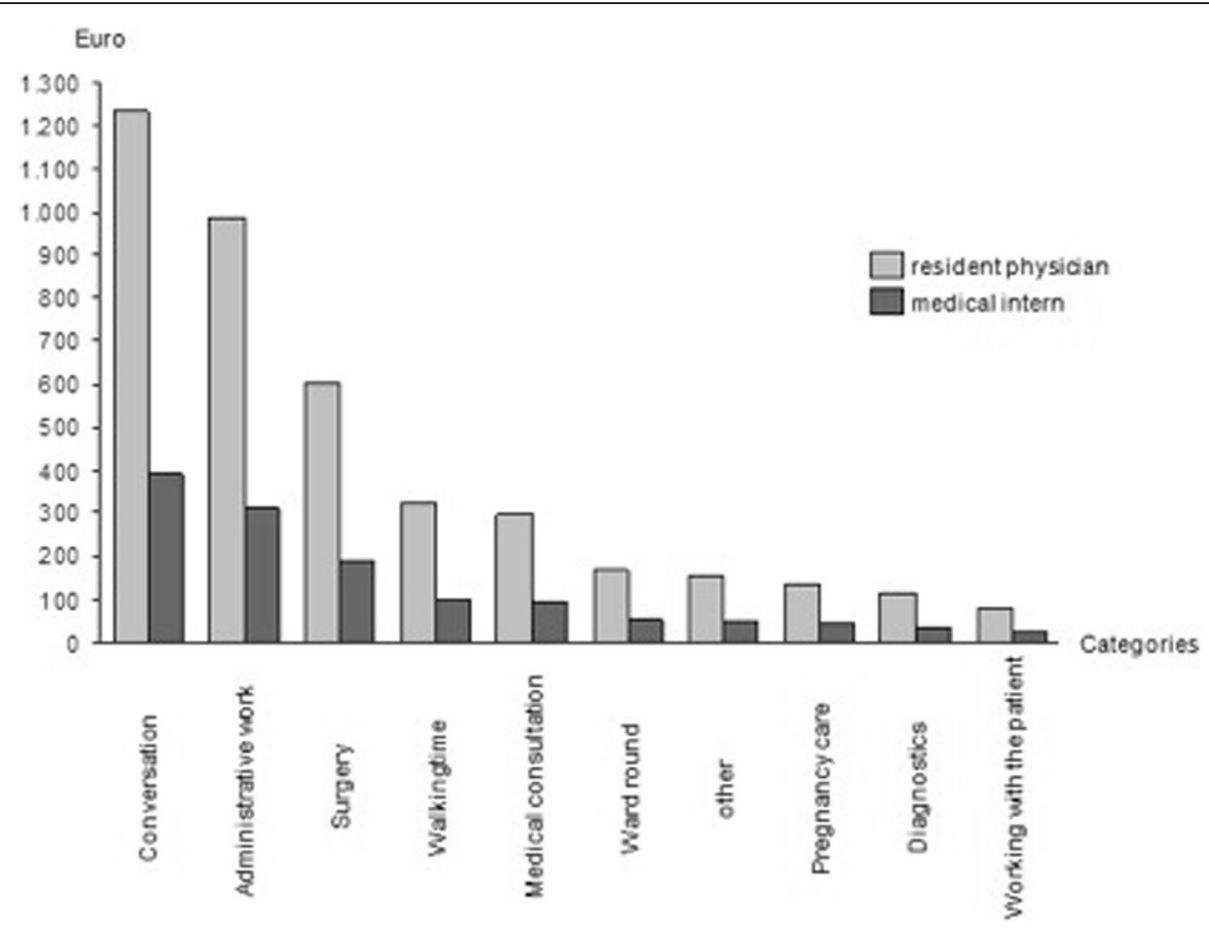

Fig. 1 Average labor costs of the most frequently main activities/month. Comparison between the historic AiP scale and the current TdL scale

MAGRO review study was to analyse the valuation for the different work activities in relation to pay scales which were paid in a 8 year intervall to physicians in their second year after the final medical exams. In this respect, it is important to notice that the reference average workday of the OB/GYNs which was identified on the basis of an analysis of more than 2 million time points was found not to be longer than 9:24:35 $\mathrm{h}(\mathrm{SD}=$ 1:05:05 h). This is shorter than anticipated and reported in other studies [47] and from these data, it cannot be stated that the average junior physician works more that 10-12 $\mathrm{h}$ per workday. Also, this amount of daily work time leads to a higher proportion of money allocated to single work tasks, as presently calculated. In this respect, we here report that i.e. the amount of salary allocated to the most frequent work task - conversation - of a physician two years after the final medical exams i.e. in the highest payment scale (TV-Ärzte TdL) is $1235.18 €$ per month $(14,822.17$ per year). This amount is more than three-fold higher than the amount allocated in the AiP payment scale (391.54 € per month and $4698.50 €$ per year). It can therefore be clearly stated that there is a significant increase of the esteem of the workforce of a junior physician on a monetary basis. This increase in the compensation dramatically differs to the public opinion of the current job situation of young doctors in Germany in 2007 [20]. This can also be concluded by comparing the reward for different work tasks. I.e. the pure walking time is rewared in current pay scales as high as a much more time-consuming work tasks, i.e. administrative work in the historic AiP pay scale. By comparing the exact values, it can be estimated that the increase in financial estimation is about 3-fold. In contrast to reports that state a difficult work situation for hospital doctors, the present study at least demonstrates a strong increase in the financial appreciation.

\section{Limitations}

The key message of the present review of data is that single work tasks and overall work of young German physicians working in $\mathrm{OB} / \mathrm{GYN}$ are presently valued about $300 \%$ higher than in the AiP pay scale. This increase in estimation influences all aspects of work life. However, the present study harbors several limitations that need to be adressed. First, our data basis refers to an average daily working time of 9:24:35 $\mathrm{h}(\mathrm{SD}=1: 05: 05 \mathrm{~h})$ which is lower than anticipated in many studies which address the occupational situation of German physicians. Although our data calcuation is based on the analysis of over 2,000,000 time points, it needs to be noted that they are of cause specific to hospital size and geographical location and should therefore be interpreted with caution. As discussed earlier, a further limitation of the MAGRO studies is that they so far only observe work that takes place on day shifts of weekdays and do not include information about medical workflow of on-call weekend and night shifts. Future studies may be extended to include these time periods in order to obtain more detailed information. 
A further limitation of the MAGRO studies is that the category of work activities was not chosen systematically. Therefore, the currently used categorization may lead to measurement bias, particularly in some categories including conversation, medical consultation, social works, and others may overlap and could lead to over measurement.

Concerning the different pay scales that were used to calculate the valuation of work, it needs to be stated that they change with time. However, we tried to identify tariffs which are used in a large proportion of hospitals, i.e. municpal, private and state-owned hospitals.

For the future, there is also a comparison analysis with senior OB/GYN doctors needed. This should adress average times for main activities and scale of salary. Due to differences of the level of professional experience, skills and duties, major differences concerning compensation and payment can be anticipatetd.

\section{Conclusion}

This is the first review that combines the data of a realtime workflow analysis with more than 2,000,000 time points with pay scale data in order to assess the merit of junior OB/GYN work tasks. With regard to the numerous scales that were used, it can be stated that there is an increase in the valuation of the work force of junior $\mathrm{OB} /$ GYN doctors of about $300 \%$. In contrast to the multitude of studies that report stressful conditions within the daily routine, the present study adds a new context to the discussion and demonstrates that at least, the work is now compensated in a more appropriate way.

\section{Acknowledgments}

We would like to thank all the physicians for their participation, Lisa Kloss for monitoring, and Gabriele Volante for help with the manuscript. We also thank Cristian Scutaru and Beatrix Kloft for the implementation of MAGRO tools.

\section{Funding}

not applicable.

\section{Availability of data and materials}

All data is available via the corresponding author.

\section{Author contributions}

$\mathrm{DB}, \mathrm{AH}, \mathrm{DQ}, \mathrm{NS}, \mathrm{DK}, \mathrm{DAG}$, and SM analyzed and interpreted the data, drafted the manuscript and were responsible for its review. DO and EMW participated in the discussion of the data. All authors read and approved the final manuscript.

Ethics approval and consent to participate not applicable.

\section{Consent for publication}

not applicable.

\section{Competing interests}

The authors declare that they have no competing interests.

\section{Publisher's Note}

Springer Nature remains neutral with regard to jurisdictional claims in published maps and institutional affiliations.

\section{Author details}

'Department of Gynecology and Obtestrics, Goethe University Frankfurt, Theodor-Stern-Kai 7, 60590 Frankfurt, Germany. ${ }^{2}$ Division of Social Medicine, The Institute of Occupational Medicine, Social Medicine and Environmental Medicine, Goethe University Frankfurt, Theodor-Stern-Kai 7, 60590 Frankfurt, Germany. ${ }^{3}$ Department of Medicine/Psychosomatics, Charité,

Universitätsmedizin Berlin, Free University and Humboldt University,

Luisenstrasse 13a, 10117 Berlin, Germany.

Received: 13 July 2017 Accepted: 26 February 2019

Published online: 07 March 2019

\section{References}

1. Cheng S, Tollefson D, He G, Li Y, Guo H, Chai S, Gao F, Gao F, Han G, Ren L, et al. Evaluating a framework for tuberculosis screening among healthcare workers in clinical settings, Inner Mongolia, China. J Occup Med Toxicol. 2018;13:11.

2. Gallegos Morales EN, Knierer J, Schablon A, Nienhaus A, Kersten JF. Prevalence of latent tuberculosis infection among foreign students in Lubeck, Germany tested with QuantiFERON-TB gold in-tube and QuantiFERON-TB gold plus. J Occup Med Toxicol. 2017;12:12.

3. Khabour OF, Al Ali KH, Mahallawi WH. Occupational infection and needle stick injury among clinical laboratory workers in Al-Madinah city, Saudi Arabia. J Occup Med Toxicol. 2018;13:15.

4. Westermann C, Wendeler D, Nienhaus A. Hepatitis C in healthcare personnel: secondary data analysis of therapies with direct-acting antiviral agents. J Occup Med Toxicol. 2018;13:16.

5. Schoffel N, Bendels MHK, Volante G, Groneberg DA. The human rotavirus infection. A review of the literature. Zentralblatt Fur Arbeitsmedizin Arbeitsschutz Und Ergonomie. 2017:67:321-3.

6. Schoffel N, Braun M, Bendels MHK, Groneberg DA. Legionellosis. The human infection with legionella. Zentralblatt Fur Arbeitsmedizin Arbeitsschutz Und Ergonomie. 2018;68:341-5.

7. Schoffel N, Braun M, Volante G, Bendels MHK, Groneberg DA. Rift Valley fever. A review of the literature. Zentralblatt Fur Arbeitsmedizin Arbeitsschutz Und Ergonomie. 2018;68:164-6.

8. Schoffel N, Klingelhofer D, Braun M, Bruggmann D, Groneberg DA. Hand, foot and mouth disease. A review of the literature. Zentralblatt Fur Arbeitsmedizin Arbeitsschutz Und Ergonomie. 2018;68:91-3.

9. Schoffel N, Klingelhofer D, Volante G, Braun M, Groneberg DA. Scabies. A literature review with emphasis on occupational aspects. Zentralblatt Fur Arbeitsmedizin Arbeitsschutz Und Ergonomie. 2017;67:158-60.

10. Alami YZ, Ghanim BT, Zyoud SH. Epworth sleepiness scale in medical residents: quality of sleep and its relationship to quality of life. J Occup Med Toxicol. 2018;13:21.

11. Juranic B, Rakosec Z, Jakab J, Miksic S, Vuletic S, Ivandic M, Blazevic I. Prevalence, habits and personal attitudes towards smoking among health care professionals. J Occup Med Toxicol. 2017;12:20.

12. Quart J, Deutsch T, Carmienke S, Dopfmer S, Frese T. Willingness to commute among future physicians: a multicenter cross-sectional survey of German medical students. J Occup Med Toxicol. 2018;13:17.

13. Sisler JD, Shaffer J, Soo JC, LeBouf RF, Harper M, Qian Y, Lee T. In vitro toxicological evaluation of surgical smoke from human tissue. J Occup Med Toxicol. 2018;13:12.

14. Buddeberg-Fischer B, Klaghofer R, Abel T, Buddeberg C. Junior physicians' workplace experiences in clinical fields in German-speaking Switzerland. Swiss Med Wkly. 2005;135:19-26.

15. Buddeberg-Fischer B, Klaghofer R, Stamm M, Siegrist J, Buddeberg C. Work stress and reduced health in young physicians: prospective evidence from Swiss residents. Int Arch Occup Environ Health. 2008;82:31-8.

16. Cohen JS, Patten S. Well-being in residency training: a survey examining resident physician satisfaction both within and outside of residency training and mental health in Alberta. BMC Med Educ. 2005;5:21.

17. Sugiura-Ogasawara M, Suzuki S, Kitazawa M, Kuwae C, Sawa R, Shimizu Y, Takeshita T, Yoshimura Y. Career satisfaction level, mental distress, and gender differences in working conditions among Japanese obstetricians and gynecologists. J Obstet Gynaecol Res. 2012;38:550-8.

18. Cammu H, Haentjens P. Perceptions of fatigue - and perceived consequences - among Flemish obstetricians-gynaecologists: a survey. Eur J Contracept Reprod Health Care. 2012;17:314-20. 
19. Stafford L, Judd F. Mental health and occupational wellbeing of Australian gynaecologic oncologists. Gynecol Oncol. 2010;116:526-32.

20. Janus K, Amelung VE, Gaitanides M, Schwartz FW. German physicians "on strike"--shedding light on the roots of physician dissatisfaction. Health Policy. 2007;82:357-65

21. Rovik JO, Tyssen R, Hem E, Gude T, Ekeberg O, Moum T, Vaglum P. Job stress in young physicians with an emphasis on the work-home interface: a nine-year, nationwide and longitudinal study of its course and predictors. Ind Health. 2007;45:662-71.

22. Mache S, Groneberg DA. Medical work assessment in German hospitals: a real-time observation study (MAGRO) - the study protocol. J Occup Med Toxicol. 2009;4:12.

23. Kloss L, Musial-Bright L, Klapp BF, Groneberg DA, Mache S. Observation and analysis of junior OB/GYNs' workflow in German hospitals. Arch Gynecol Obstet. 2010;281:871-8.

24. Mache S, Kelm R, Bauer H, Nienhaus A, Klapp BF, Groneberg DA. General and visceral surgery practice in German hospitals: a real-time work analysis on surgeons' work flow. Langenbeck's Arch Surg. 2009.

25. Mache S, Kloss L, Heuser I, Klapp BF, Groneberg DA. Real time analysis of psychiatrists' workflow in German hospitals. Nord J Psychiatry. 2011;65:112-6.

26. Mache S, Vitzthum K, Klapp BF, Groneberg DA. Doctors' working conditions in emergency care units in Germany: a real-time assessment. Emerg Med J. 2011.

27. Mache S, Busch D, Vitzthum K, Kusma B, Klapp BF, Groneberg DA. Cardiologists' workflow in small to medium-sized German hospitals: an observational work analysis. J Cardiovasc Med (Hagerstown). 2011;12:475-81.

28. Mache S, Schoffel N, Kusma B, Vitzthum K, Klapp BF, Groneberg DA. Cancer care and residents' working hours in oncology and hematology departments: an observational real-time study in German hospitals. Jpn J Clin Oncol. 2011:41:81-6.

29. Mache S, Scutaru C, Vitzthum K, Gerber A, Quarcoo D, Welte T, Bauer TT, Spallek M, Seidler A, Nienhaus A, et al. Development and evaluation of a computerbased medical work assessment programme. J Occup Med Toxicol. 2008;3:35.

30. Bauer J, Groneberg DA. Physicians' working conditions in hospitals from the students' perspective (iCEPT-study)-results of a web-based survey. J Occup Med Toxicol. 2016;11:5.

31. Pantenburg B, Luppa M, Konig HH, Riedel-Heller SG. Burnout among young physicians and its association with physicians' wishes to leave: results of a survey in Saxony, Germany. J Occup Med Toxicol. 2016;11:2.

32. Perez-Diaz C, Calixto OJ, Faccini-Martinez AA, Bravo-Ojeda JS, Botero-Garcia CA, Uribe-Pardo E, Mantilla-Florez YF, Benitez F, Duran A, Osorio J. Occupational exposure to blood borne pathogens among healthcare workers: a cross-sectional study of a registry in Colombia. J Occup Med Toxicol. 2015;10:45.

33. Diel R, Loddenkemper R, Nienhaus A. Consequences of tuberculosis among asylum seekers for health care workers in Germany. J Occup Med Toxicol. 2016;11:4.

34. Appel P, Schuler M, Vogel H, Oezelsel A, Faller H. Short questionnaire for workplace analysis (KFZA): factorial validation in physicians and nurses working in hospital settings. J Occup Med Toxicol. 2017;12:11.

35. Bruggmann D, Groneberg DA. An index to characterize female career promotion in academic medicine. J Occup Med Toxicol. 2017;12:18.

36. Seidler A, Schmeisser G, Selbig M, Drews A, Hammer I, Liebe S, Nowak M, Riedel-Heller S, Weiss M, Catrein B, et al. Employing pregnant surgeons in the operating theatre. Zentralblatt Fur Arbeitsmedizin Arbeitsschutz Und Ergonomie. 2018;68:27-9.

37. Nubling $M$, Vomstein $M$, Haug A, Lincke HJ. Are reference data from the COPSOQ database suitable for a JEM on psychosocial factors at work? Zentralblatt Fur Arbeitsmedizin Arbeitsschutz Und Ergonomie. 2017;67:151-4.

38. Michaelis M, Hofmann FM, Stossel U, Hofmann F. Norovirus outbreaks and cooperation between occupational health physicians and hygiene personnel in hospitals. Results of a survey among congress participants. Zentralblatt Fur Arbeitsmedizin Arbeitsschutz Und Ergonomie. 2017;67:309-13.

39. Mache $S$, Harth $V$. Job satisfaction in the context of compatibility of work and private life. Zentralblatt Fur Arbeitsmedizin Arbeitsschutz Und Ergonomie. 2017;67:291-6.

40. Lojewski J, Harth V, Mache S. Stressors for pregnant women at the workplace. Coping and possible consequences. Zentralblatt Fur Arbeitsmedizin Arbeitsschutz Und Ergonomie. 2017;67:40-3.

41. Kordsmeyer AC, Harth V, Mache S. Supportive strategies for pregnant women at the workplace. Zentralblatt Fur Arbeitsmedizin Arbeitsschutz Und Ergonomie. 2018;68:113-7.
42. Eickmann U, Thullner I. Working with formaldehyde in the healthcare service. What are appropriate protective measures? Zentralblatt Fur Arbeitsmedizin Arbeitsschutz Und Ergonomie. 2017;67:22-31.

43. O'Meara AT, Averette HE. Job satisfaction among gynecologic oncologists practicing in the United States. Gynecol Oncol. 2000;76:163-9.

44. Gordinier ME, Ramondetta LM, Parker LP, Wolf JK, Follen M, Gershenson DM, Bodurka-Bevers D. Survey of female gynecologic oncologists and fellows: balancing professional and personal life. Gynecol Oncol. 2000;79:309-14.

45. Elit L, Trim K, Mand-Bains IH, Sussman J, Grunfeld E. Job satisfaction, stress, and burnout among Canadian gynecologic oncologists. Gynecol Oncol. 2004;94:134-9.

46. Blazek BA, Zollinger TW, Look KY. Obstetrics-gynecology resident satisfaction. Am J Obstet Gynecol. 2005;193:1798-803.

47. Cougot B, Petit A, Paget C, Roedlich C, Fleury-Bahi G, Fouquet M, Menu P, Dubois C, Geraut C, Roquelaure Y, Tripodi D. Chronic low back pain among French healthcare workers and prognostic factors of return to work (RTW): a non-randomized controlled trial. J Occup Med Toxicol. 2015;10:40.

\section{Ready to submit your research? Choose BMC and benefit from:}

- fast, convenient online submission

- thorough peer review by experienced researchers in your field

- rapid publication on acceptance

- support for research data, including large and complex data types

- gold Open Access which fosters wider collaboration and increased citations

- maximum visibility for your research: over $100 \mathrm{M}$ website views per year

At BMC, research is always in progress.

Learn more biomedcentral.com/submissions 